\title{
Development and territory: potentialities of the Yachay city of knowledge in Ecuador
}

Mariana Lima Bandeira

limabandeira.mariana@gmail.com

Ecuador

Cézar Augusto Miranda Guedes cezar.eco@gmail.com

Universidade Federal Rural do Rio de Janeiro, Rio de Janeiiro, Brasil

Marcelo Fernando López-Parra ferlopezparra@gmail.com Ecuador

\begin{abstract}
This study aims to approach the concept of development from the perspective of what Andean indigenous peoples call Sumak Kawsay, a notion which emerges as a counterhegemonic discourse that challenges the dichotomy of peripheral vs. central countries. In our argument, the ideological vision of Buen Vivir [Good Living], orSumak Kawsay, combines with Jorge Sábato's triangle conceptto provide a basis for proposingan Innovative Statein order to transcend the vision of dependency and of countries considered as peripheral, like Ecuador in today's context.To that end, we analyze a case study, the Yachay City of Knowledge, a complex of innovation in which society, university and companies should coexist, and which this article analyzes in terms of the potential it would have due to its original concept. The study was based on bibliographical and documentary information which we examinedusing content analysis. Among the main findings, it is noteworthy that the obstacles identified are mainly related to management problems and to disarticulation between the vertices of the Sábato Triangle (which represents thestate, the infrastructure/academia and businesses) - whether concerningtheir functionality, their importance or the responsibility they should assume.
\end{abstract}

KEY WORDS: Development, Sumak Kawsay, Yachay City of Knowledge, Ecuador. 


\section{INTRODUCTION}

Ecuador has been seeking, through public and social policies, to integrate social and economic development. To that effect, it has promoted its selfproclaimed "Citizen Revolution" for the last ten years. In this context, the country has launched important integration initiatives that consist in innovation projects created from an entrepreneurial state viewpoint. One of them is known as the Yachay City of Knowledge, a complex of innovation in which society, university and companies should coexist, and which this article analyzes in terms of the potential it would have due to its original concept.

In our argument, the ideological vision of Buen Vivir [Good Living], or Sumak Kawsay, combines with Jorge Sábato's triangle concept to provide a basis for proposing an Innovative State in order to transcend the vision of dependency and of countries considered as peripheral, like Ecuador in today's context.

This study aims to approach the concept of development from the perspective of what Andean indigenous peoples call Sumak Kawsay, a notion which emerges as a counter-hegemonic discourse that challenges the dichotomy of peripheral vs. central countries.

Generally speaking, the Yachay project, which the Ecuadorian government carried out from 2010 to 2017, sought an alternative to the commodity-based growth model which creates permanent dependence on the countries that form the capitalist system's organic core (ARRIGHI, 1997)

Thus, Yachay is essentially about strengthening a society that is constitutive of its territory, critical and participatory of its surroundings. Public policies, with their respective instruments and dynamics, promise to build legitimacy in order to promote local and regional development in a broad sense. Our purpose is not to present anassessment of public policy, but rather to describe, based on official documents, bibliographic and documentary information, the potential of - and deviations from - this proposal, whichwas launched by the government to consolidate a perspective of independence and which can serve as a modelto the region.

Methodologically, thisstudy was based on bibliographical and documentary information which we examined using content analysis. We defined the main categories of analysis based on the three vertices of the Sábato triangle for innovation and development, namely State, Infrastructure/Academia and Business Fabric. Documents were processed usingcontent analysis software, which allowed establishing the similarities and differences between the discourses of each set of institutions representing the vertices.

In the beginning of the 21st century, Latin America stood out for its various leaders, who emphasized a state role more concerned with a social development that might go hand in hand with economic development and hopefully promoteit through social and productive inclusion. From this premise, and as a pillar of a development conceived from the logic of peripheral countries (SUNKEL, 1968; SANTOS, 2015), Ecuador innovated the discourse of development with the selfdescribed citizen revolution(COBEY\&BANDEIRA, 2016; SILVA\&GUEDES, 2017)and launched important integration initiatives that consist in innovation projects created from an entrepreneurial state viewpoint (MAZZUCATTO, 2013). 
One of the justifications for fostering a "Schumpeterian" state emphasizes the need for social innovation, due to ever more scarce resources; therefore, it is necessary to call upon society to participate in this project. In fact, as Mazucatto (2013) says, innovation is always a collective project.

The context, at the time of the Yachay project (2008 to 2014), was considered favorable by governmental authorities. Ecuador started to gain international visibility and, due to its economic and political instability, it would be fruitful to build a capacity to develop other sectors of the economy and become a model in the production of knowledge. In the public policy practiced until 2016, there were concrete, direct and symbolic incentives for technological development combined with social development. In addition, higher education policy dedicated to developing technology and diverse knowledge areas, the citizen revolution discourse and a state planning through the Plan Nacional de Buen Vivir [National Plan of Good Living] (PNBV)were instruments that contributed to develop the city of knowledge.

The project received considerable criticism (VILLAVICENCIO, 2013, 2014, 2015) and still faces resistance (BRAÑA, DOMÍNGUEZ \& LEÓN, 2016). Moreover, despite the discourse about a "change in the production mix", Ecuador was still (until 2017) in a fragile position in the world market, a scenario worsened by oil price fluctuations and fiscal adjustment policies. Currently, the political crisis related to the government transition, as well ascorruption allegations, have reduced the trust of society, causing the emergence of a context more complex than the one in which the project was conceived.

Considering the scenario we briefly explored above, our study intends to show the upside and range of this initiative, articulating it to the model proposed by Jorge Sábato more than five decades ago. In 1967, Jorge Sábato and Natalio Botana presented an analysis on the role of science and technology in Latin America's development. The authors' presentation took place at a meeting in Santiago, Chile, where a prospective vision of both Latin America and the world order for the 1990s was projected. This text also appears in 1968 (at a conference on Models of World Order, in Italy) and in the La Revista de la Integración journal (SÁBATO \& BOTANA, 1968). In 1970, it became a chapter in a compilation on the same theme (Latin America: Science and Technology in the development of society) with works by several renowned Latin American social scientists (Herrera, 1970). In 2004, more than twenty years after his death, this chapter includes a piece in honor of Jorge Sábato (2004), in which that co-authorship is not mentioned.

Jorge Sábato advocates scientific-technological research as a "powerful tool to transform a society" (SÁBATO \& BOTANA, 1970, p.59) and, most of all, that science and technology should serve the progress of Latin America, enhancing its independence in socioeconomic terms (SÁBATO, 2004; SÁBATO \& Botana, 1967, 1968, 1970). The origin and context of this debate is extremely important, considering that Jorge Sábato's proposal is often confused with Etzkowitz's Triple Helix concept (1993).

The Sábato triangle, as it is known today, aims to distribute the responsibilities for scientific and technological development among the three vertices of a triangle, defined according to their social role. Technological infrastructure, defined as the complex of interrelated elements (education 
system, laboratories, institutional framework, funding, among others); the production structure, defined as the set of actors capable of incorporating the knowledge generated (innovation) so as to create or modify a productive process; and the government, responsible for the political institutionalization of this dynamic (through political tools and socio-cultural constructions). The idea of linking them togetherthrough the triangle symbol is very significant as it assumes the need for balance, co-responsibility and joint action among the three main actors.

On the other hand, the triple helix concept differs in several aspects. Its central premise lies in generating innovation to maintain a more efficient and effective capitalist system, so as to maintain the differentiation between central and peripheral countries. In addition, its initial proposal focused on the university, considering it responsiblefor producing knowledge and driving the process of innovation and articulation with businesses.

This article is organized in five sections, in addition to the introduction. Initially, we present the theoretical bases that guide our reflections, thenour methodology, including details of the survey and the analysis performed. The third section, with its subdivisions, describes the context and the case study, and provides information specifically about the Ecuadorian model of government. The fourth section is dedicated to presenting results of the content analysis. Finally, we propose some reflections about the breadth Jorge Sábato's proposal, whose line of elaboration and analysis remains up-to-date and revitalized by the historical trajectory of science and technology in Latin America.

\section{SCIENCE AND TECHNOLOGY: DIFFERENT PERSPECTIVES ON DEVELOPMENT FOR LATIN AMERICA}

Since the late 1980's, the triple-helix model became established as the best way to promote innovation. The idea of building innovative enterprises with support from universities dates back to the period of the U.S. Great Depression. Its author was the then president of the Massachusetts Institute of Technology (ETZKOWITZ, 1993). The main argument revolved around the importance of research to produce new technology and promote a new type of industrial development.

Initially, there was resistance by the government, but the alliances built at the time were able generate enough infrastructure to carry out this proposal. Gradually,the relationship between universities and the industrial sector took on a more legitimate form.

The triple helix model was built on the premise that knowledge bothfounds and is founded upon economic development;thus, the relations between university, industries and government must be complementary (ETZKOWITZ, 1995). It is noteworthy that this relationship is proposed in a context of industrial development (ETZKOWITZ \& LEYDESDORFF, 1998) and that government was the last to join it. The protagonist role is divided between the university and the productive sector, with both of them seeking to protect theirown interests. The assumption of a crisis in science mobilized this relationship and included government into it. 
However, this is still a time of transition (ETZKOWITZ \& LEYDESDORFF, 1998), one in which government and companies reconsider the "use" of science as they "cooperate and compete" (p.207).

Although a triple helix is used to symbolize this model, the dichotomous relationships (company-university, government\&company-university) remain. It is a model designed for economic development, for promoting small and medium enterprises that primarily articulate the three actors to carry out a project. A recent text identifies a few differences between the two proposals (ZHOU \& ETZKOWITZ, 2017).

Sábato (2004) denounces how scientific-technological research has become an instrument of domination by powerful nations and entities to form a 'technological neocolonialism'. Based on studies by Osvaldo Sunkel, the author reinforces that countries in the "center" develop expertise in generating new scientific and technological knowledge, and what is left to "peripheral" countries is consuming and routinely using it.1

Some Latin American authors have been more concerned with these issues and have actively built alternative discourses to transcend this perverse "coloniality" dynamic. Among them, it is worth mentioning Amílcar Herrera,2Eduardo Dvorkin, Renato Dagnino, Ivo Theis, Jorge Katz, Jose Antônio Ocampo,who, consistently with Jorge Sábato's proposal, lead us to reflect on the justifications that are used to maintain the central-peripheral dichotomy.

Sábato (2004) says that the nature of the problem and its causes are basedon myths, paradoxes and sophisms that paralyze technological development, and that they are an obstacle to sustainable technological development. The author provides a set of responses based on Argentina's scenario, but his arguments are proportionally valid for the case studied in the present work.

Initially, he vehemently denies that no science is being done in Argentina, thus recognizing that what little is being done must be acknowledged. As to the number of researchers, Sabato recognizes that they are few - particularly compared with the US and France; still, there was a significant brain drain, to which he poses his paradox: "we lack researchers, and yet we export them" ( $p$. 30). With regard to financial resources, the author compares the country's figures for S\&T investmentwith those for royalty payment to show that the latter amounts to nearly three times as much as the former. In addition, of the funds for S\&T research and development, much is inefficiently used or wasted.

Another point worth mentioning is his argument about the articulation between research and the existence of large companies. Sábato talks about technological development arising from small initiatives and in various fields, not just in what could be considered cutting-edge technology. In addition, he questions the fact that the state, which possesses large companies, is also

${ }^{11}$ We recommend reading SUNKEL, O. La universidad latinoamericana ante el avance científico y técnico: algunas reflexiones. Estudios Internacionales Año IV, No. 13, abril-junio, 1970; and SUNKEL, O. El marco histórico del proceso de desarrollo y subdesarrollo. Cuadernos ILPES, Serie II, No. 1, Santiago, Chile, 1967.

Despite the dates of these publications and the advances in certain Latin American countries regarding investment in research, as well as the dynamism that academy has shown in disseminating results, the central and peripheral positions have not yet Pásibstahtially changed. Therefore, this discussion remains up-to-date and relevant.

${ }^{2}$ See: HERRERA, A. La ciencia en el desarrollo de América Latina. Estudios Internacionales. Año 2, No. 1, abril-junio, 1968. 
responsible for the decision not to invest in technology; in this respect, he compares the decisions of international companies with the same revenuewhich allocate part of their budget to research and development. Finally, a very common and perverse argument that Sábato challenges is that "it is simpler, cheaper and safer to import knowledge" (p.37).The author lists a set of reasons for building negotiation capacity and decision-making autonomy on natural resources, the focus of industrial development (i.e., the type of industry to be developed), investment prioritization, local development and the designing of strategies and public policies for the country's sustainable development, among others.

Herrera (1968: 32) concludes: "to renounce scientific creation, one of the basic manifestations of a society's creative will, so as to become mere intellectual appendices of advanced nations, is to renounce the real possibility of development".

Thus, the authors explore the nature of the problem as a paradigmatic construction of society itself, built upon fallacious arguments and actually sustaining a dependency that becomes real dueto the little importance given to the development of the country's own capacity to generate knowledge, science and technology.

Sábato's (2004) proposalconsists of demystifying and deconstructing these arguments to present his triangle as way of converging the country's development efforts, since scientific-technological research can translate into "infinite possibilities as an instrument of transformation" which is essential to a nation's sovereignty. The power of this argument calls for thinking of a process of building sovereignty that is pervaded by autonomy, non-dependence and the ability to make decisions to promote local development according to the needs of local society.

According to Sábato (2004), if a country can, through a conscious political process, introduce science and technology into the "development fabric" and decide how and where to innovate, then its sovereignty is consolidated. This process is represented by three core areas, three coordinated elements: Infrastructure, Government and Productive Structure. Although Sábato named it the IGE triangle (2004, p.42), it is now known as the Sábato triangle.

\section{METHODOLOGY}

The present work is a case study. According to Eisenhardt (1989), case studiesallow building hypotheses about themes or objects of study that are not well researched due to their particularities.

Thus, we used content analysis to examine our documentary sources. This technique relies on an objective and systematic description that allows describing and interpreting the contents and narratives of the messages.

Due to the nature of our material, we chose one from the three approaches to content analysis, i.e., the summative approach (HSIWH \& SHANNON, 2005). In this respect, Laurence Bardin (2002) recommends reading the material superficially at first in order to make a first approximation to the categories, using 
the word cloud or mapping resource.

This feature is provided by $\mathrm{N}$ Vivo software, and it organizes, identifies and systematizes converging and diverging terms according to theory-defined categories. The advantage of using this software is that it allows analyzing many texts and messages simultaneously, thus giving the researcher more time to look deeper into and interrelate the characteristics of the messages, besides facilitating the process of interpreting implied messages. Confronting manifested and implicit messages allowsrecovering the symbolic system which underpins the social imaginary.

The material we analyzed consists of a few documents which are key to the project's framework, namely:

- Yachay Creation Record (three volumes) - approximately 1,800 pages;

- Plan Nacional del Buen Vivir (2007-2010) - 458 pages;

- Plan Nacional del Buen Vivir (2009-2013) - 520 pages;

- Plan Nacional del Buen Vivir (2013-2017) - 602 pages.

- The national strategy for transformingthe production framework - 120 pages.

- The guidelines for developing the Ecuador Industrial Policy - 158 pages

Initially, the material was introduced into the $\mathrm{N}$ Vivo software's database to produce a cloud with the most used words for each set of material. The first set consists of the Yachay Creation Record's three volumes; the second volume corresponds to the three versions of the PNBV; the third volume corresponds to the materials of the national strategy for transforming the production framework and the document about Ecuador's industrial policy.

Then, using the categories previously defined by the literature, as well as the new categories we identified by exploring the respective word clouds, we searchedthe documents for the terms (categories) to see in which context they were being used.

Finally, we analyzed the correlation between all documents in order to examine the closeness between the public policies based on the documents analyzed.

Results were systematized, and the next section presents a description of the country's socioeconomic and political context, a brief presentation of its governance model during the period studied, asummarized history of case study and the results of the content analysis of the documents studied.

Since the documents are in Spanish, we presented the two figures - i.e., the cloud and the map -in the original language. Through the analysis of content, we expect that results can be understandable.

\section{UNDERSTANDING ECUADOR'S ECONOMIC, SOCIAL AND POLITICAL CONTEXT}

Ecuador's territory covers 256,370 square kilometers, and the country's population is an estimated $16,385,068$ people (BANCO MUNDIAL, 2016), with an 
average of 63 inhabitants per square kilometer. The country's largest cities are: Quito, the capital, which according to the National Institute of Statistics and Censuses of Ecuador (INEC, 2017) is home to about 2.5 million inhabitants, located 2,850m above sea level; Guayaquil, a port and commercial city which is the most populous in the country, with 2,644,891 inhabitants; and Cuenca, which is considered the cultural cradle of Ecuador and has 603,209 inhabitants, making it the country's third most populous city.

The economy has been dollarized since 2000, with a (nominal) GDP of US\$ 97,802 billion (in 2016, World Bank), its main industries being oil, manufacturing and agriculture. In 2015, GDP was divided as follows: services (59.7\%), manufacturing (12\%), oil (11\%) and agriculture (7\%) - (estimates for 2015).

According to World Bank information, from 2006 to 2014, there was an average GDP growth of $4.3 \%$ due to high oil prices and significant flows of external credit for the public sector. This allowed for greater public spending, social spending and significant investments. During this period, poverty decreased from $37.6 \%$ to $22.5 \%$ and the Gini coefficient declined from 0.54 to 0.47 . The country's HDI for the 2014-2015 period was 0.739(89th position); in 2005, HDI was 0.68 (UNDP, 2015).

However, this result is at risk due to the oil crisis and to US dollar appreciation, and these factors were aggravated by the earthquakes that affected the country's coast in 2016. In addition, the political scenariois still stabilizing with a new president, while the fight against corruption and the efforts to establish trust in society have sloweddown the pace of response by the Ecuadorian economy.

Also according to World Bank, the lack of a local currency and of fiscal savings led the Ecuadorian government to reduce public investment and tightly control current expenses. This policy or strategy reflects heavilyon the current administration of President Lenin Moreno, who took office in 2017.The previous authorities also resorted to different sources of external and domestic credit, some of which were not so beneficial to the country, according to current debates. Nevertheless, the World Bank recognizes that these policies allowed to temporarily mitigate the effects of low oil prices and to finance post-earthquake reconstruction, while increasing public debt.

Despite the new president's inauguration, this is a complex period in which Ecuador faces the challenge of achieving the necessary political consensus to adapt its economy to the new international contextin order to resume the path of sustainable growth with greater participation of the private sector and ensure the progress and success of social development as in the boom years.

\section{Fundamentals of the Ecuadorian Government Model}

The government model promised ruptures with the condition of dependence and of being a peripheral country and was known in the context of 21st century socialism as the Buen Vivir or Sumak Kawsay model. This development model adopted an ideology based on an Andean worldview denominated Sumak Kawsay. More than a paradigm or way of thought, this ideology was translated into political and social guidelines, and Ecuador became the first country to 
include the rights of nature and to declare the country as plurinational in the Constitution of 2008. In the Constitutions of Ecuador and Bolivia "por primera vez se toma un concepto de las tradiciones indígenas como base para el ordenamiento y legitimación de la vida política" ["for the first time a concept of indigenous traditions is taken as the basis for the framework and legitimation of political life" ].3

The central idea is to recover the experience of ancestral cultures. As a starting point, Sumak Kawsay reflects the fullness of life, the harmony between all living beings and their surroundings, the acceptance, integration and empowerment of different life forms. For the Andean people, there is no conception of a linear history in which the previous and the subsequent to a state of things are defined. Nor can one accept the idea of a state of underdevelopment that must be overcome or a state of development to be achieved. Social life is not thought of in this dichotomy. Nor did indigenous peoples have the concept of poverty associated with the lack of material goods or wealth associated with the abundance of goods.

The greatest contribution, therefore, lies in the invitation to take on other possibilities for growth and development, rather than just accept that there is one path to development. Therefore, this perspective becomes a rupture with thehegemonic modernizing thinking. The proposal is that by transplanting this ideology into public policy, within government, there can be the strengthening of national cohesion, collective values and the active participation of individuals and collectivities in decisions relevant to the construction of their own destiny and happiness.

Public policy in Ecuador is explicitly based on the ideology of Sumak Kawsay, an indigenous term that can be translated into Spanish as Buen Vivir [Good Living](WALSH, 2010; GUDYNAS, 2011). The literal translation, however, cannot convey the full meaning of the term. A maximum simplification is to interpret it as 'collective well-being' and, when applied to public policy, this concept leads to assuming these basic principles: tolerance, respect for diversity, fostering the inclusion of historically excluded minorities so they can access their rights, and protecting generalized equity and the full sovereignty of the people. The concept applied to the Ecuadorian system of government also invites to take on a perspective on development based on the values of citizenship and sustainability (COBEY \& BANDEIRA, 2013).

This concept provokes the reflection that proposals by the government are consistent with the foundations of dependency theory, as it invites to a different reflection on what sovereignty and development mean.

As discourses of the model, the Citizen Revolution and the National Strategy for Transforming the Production Framework seek social empowerment throughdiscussion tables on public policies and creation of a complex regulatory framework, development of the country's infrastructure, social inclusion into various public services, public-private partnerships/alliances and financial and symbolic incentives.

| ${ }^{3}$ htttp://www.buenvivir.gob.ec/el-socialismo-del-buen-vivir 


\section{Object of Study: The YACHAY Project}

Cities of knowledge can be defined based on their principles and their main goal. A city of knowledge consists of an articulation between various social actors whocome together to build an economy based on knowledge and innovation production relating to its various aspects, such as technology, knowledge, society, among others. Ergazaki et. al. (2006) argue that a key feature of a city of knowledge is massive investment in education, training and research.

These urban spaces are planned around a set of elements which are meant to provide themwith sustainability and contribute to their main purpose: being a source of knowledge (ROMEIRO \& GUTIÉRREZ, 2008). They are expected to have sufficient resources, infrastructure, services, human talent and a management system to institutionalize capacities in the social environment and achieve knowledge transfer.

There are some initiatives of this type, with different degrees of success, that could be listed in this study. In Latin America, two examples can be mentioned, namely Panama and Mexico. However, the Korean example, which is well known for its trajectory, its historical and cultural constructions and its results, served as a model for initiatives such as the one in Ecuador. Its logic is assumed to primarily serve developmentalism. Thus, by transferring this experience to a socially, culturally and historically different context, such as that of Ecuador, this model might need adjustments to present the expected results.

According to a 2011 SENPLADES technical report (ECUADOR, 2011), the Yachay City of Knowledge was built in a valley surrounded by mountains in the country's north-west, in a11,092-acre area. It is a fertile region whose springs, climate and geographical conditions are conduciveto biotechnological and agricultural experiments and it is located near a city called Ibarra. It is considered a geographically privileged location, as it is $115 \mathrm{~km}$ from the international airport of Quitoand near the country's northern border (with Colombia).

The project was developed by a Korean company (ECUADOR, Plan Maestro, 2013), whose guidelines were strategically defined considering urban ecology, land use, mobility, urban dynamics and civic integration. Location was considered the first challenge for building legitimacy as it should contributeto the chosen area's endogenous and exogenous development.The project promised to improve and create housing, commercial businesses and communication networks which has not been addressed by other government strategic projects. It also planned to promote Buen Vivir in rural areas and strengthen food sovereignty, as well diversity and cultural heritage for sustainable development.

\section{CONTENT ANALYSIS RESULTS}

The word cloud with the 50 most used terms in the three volumes of the Yachay Creation Record shows the following result: 
Figure 1-The 50 most used words in the Yachay Creation Record.

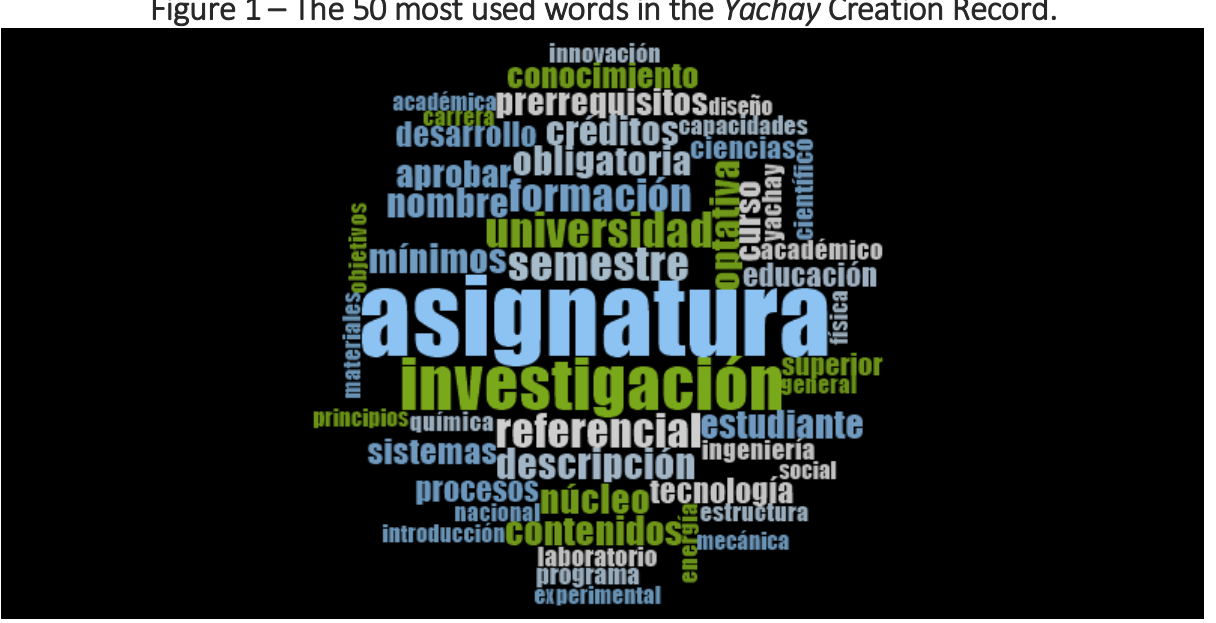

Source: Expediente Yachay, 2013.

As Figure 1 shows, the nearly two thousand pages of the creation record do not markedly include the discourses used for their justification, e.g.,production framework transformation and knowledge production.

We sought terms that could representSábato's three vertices, but the word maps we found showed no articulation between them. The words we chose were: Buen Vivir, development, autonomy, science, knowledge, government, productive sector, businesses, investment, innovation and production framework. We associate Buen Vivir, development and production frameworkwith the Government vertex; autonomy, innovation, knowledge and science with the Infrastructure vertex; and enterprise, productive sector, businesses and investment with the Company vertex.

Table 1 - Frequency of Terms Characteristic of Sábato's Triangle

\begin{tabular}{|c|c|}
\hline Words & Frequency \\
\hline Buen VivirandSumak Kawsay & 145 times \\
\hline Development & 643 times \\
\hline Autonomy & 17 times \\
\hline Knowledge & 665 times \\
\hline Innovation & Not once \\
\hline Science & 527 times \\
\hline Company & 72 times \\
\hline Productive Sector & 241 times \\
\hline Businesses & 38 times \\
\hline Investment & 67 times \\
\hline Production Framework & 140 times \\
\hline
\end{tabular}

Source: Results of this study, 2018.

This result makes sense when we analyze the context in which the words are used. Because the graphs are too long, we will illustrate the path we took in our 
analysis and systematize the other results. Thus, we will describe how the term Matriz Productiva [Production Framework] is used in the context of the Yachay Creation Record. Figure 2 shows a map of relationships in which the term appears in the text. There are some word groups in which the term combines with others to build the context in which the meanings are constructed.

Thus, the map shows that the terms associated with "cambio de la matriz productiva" ["change in the production framework"] (left side) still have an ambiguous connotation. That is visible when the verbs appear in the infinitive, in conditional forms or in the future tense, e.g., "fortalecer", "contribuyan" and "aportará" ["to strengthen", "would provide" and "will contribute"], respectively - or articulated to terms immersed in a common discourse, e.g.: "concebierse como una universidad", "la cual tiene implicaciones directas", "lo que facilitará el acesso" ["be conceived as a university", "which has direct implications", "which will facilitate access"], etc.

Generally, in Figure 2, the terms on the right articulate more clearly with the university. However, what stands out most is that the term Matriz Productiva is emptied of concept as there is a multiplicity of terms associated, and they do not establish an identity with any of Sábato's vertices. 
Figure 2 - Word Association Map, Matriz Productiva [Production Framework]

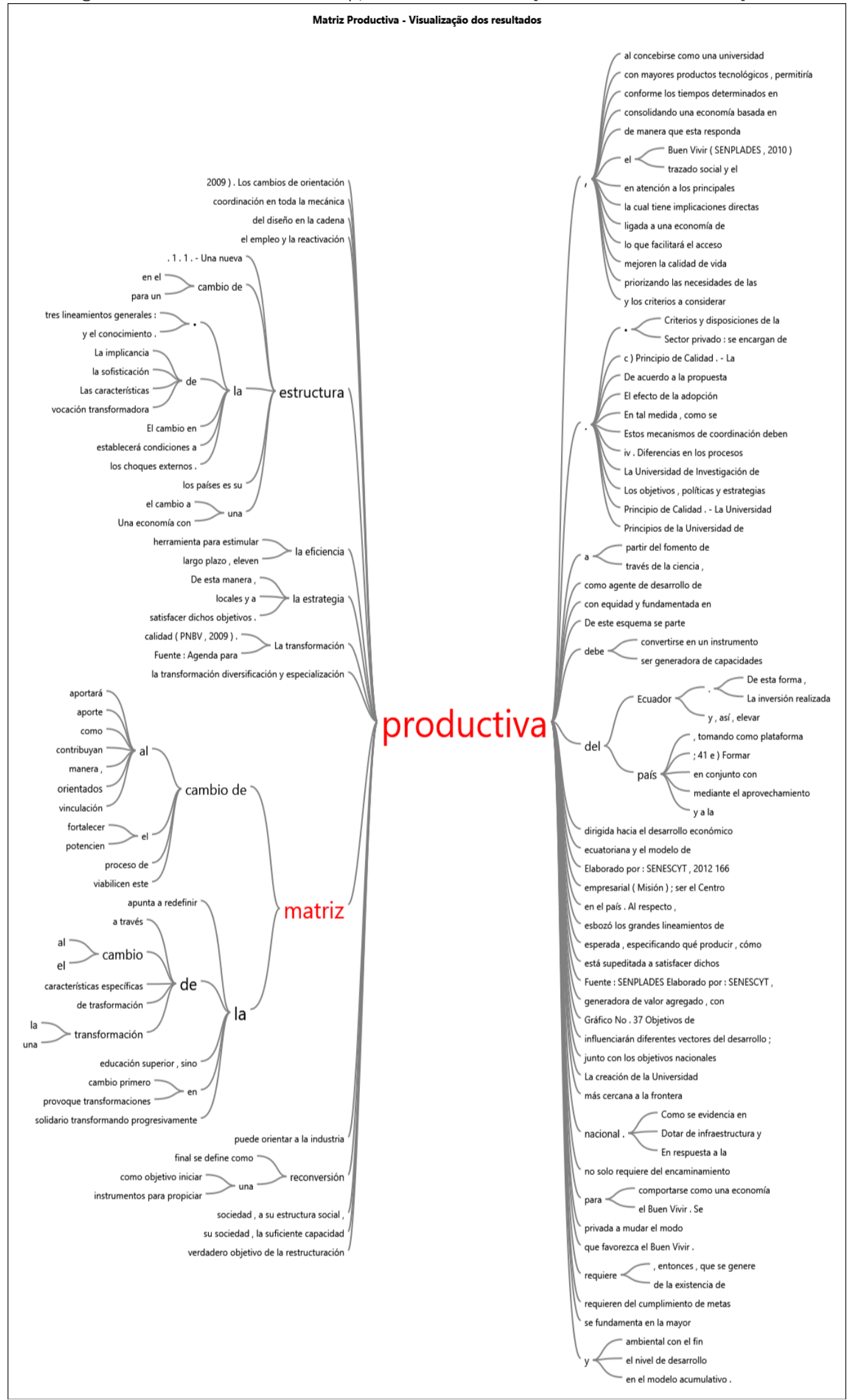


By analyzing the other documents, we found a logic of internal articulation, as though each document were only discussing within its own internal linguistic structures and they somehow showed a clear dispersion in the association of concepts. We also found that the documents linked to production framework transformation reinforced innovation as though it were a function of businesses. The documents on the university's role dealt more clearly with scientific knowledge production as the core of innovation. And the PNBV documents articulated the government's ideology in an explicit manner. In practice, what stands out is a disarticulation between the three main innovation actors.

Finally, in the cluster analysis between the analyzed documents, using the Pearson's Coefficient, this fragmentation is shown in Figure 3.

Fontes em cluster por similaridade de palavra

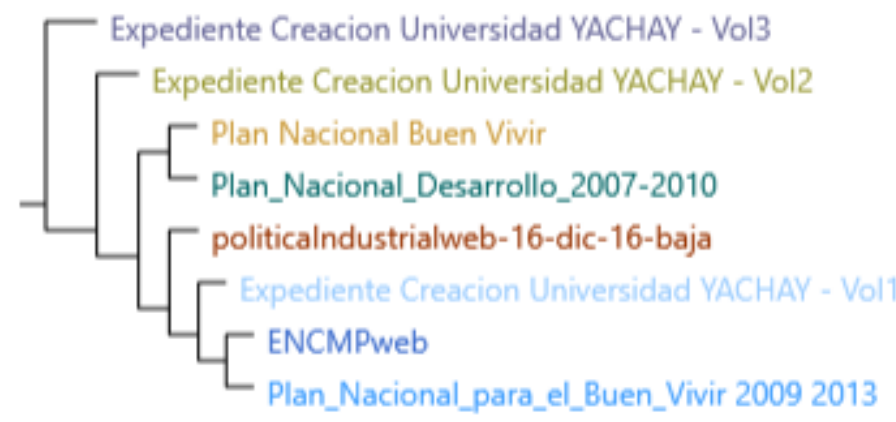

Figure 3 -Word Similarity Cluster

Source: Results of this study, 2018.

[Tradução da figura: YACHAY University Creation Record - Vol3;

YACHAY University Creation Record - Vol2;

National Good Living Plan;

National Development Plan;

Industrial Policy;

YACHAY University Creation Record - Vol1;

National Strategy for Transforming the Production Framework (ENCMP);

National Plan for Good Living 2009-2013.]

We interpret this result according to the existing nexuses, which reflect on the colors and connections. Thus, the National Strategy for transforming the production framework presents more common terms than the PNBV in its second version. We also interpret that the PNBV's last version has more similarities withits first version. Industrial policy is isolated, but it articulates with the set of documents in blue.

The connections in Figure 3 only reinforce the discourse fragmentation and the disarticulation between the vertices; perhaps this dispersion indicates somehow the difficulty to build innovation from a concept of development that is different from the institutional environment; or perhaps it indicates that, in fact, innovation and knowledge production materialize from a micro institutional perspective. 


\section{FINAL CONSIDERATIONS: THE STRENGTHS OF EACH VERTEX}

The theoretical elements and the results of this empirical study indicate that the Ecuadorian model of government proposes some epistemological and conceptual ruptures. Among these, the adoption of an ideology based on the Andean worldview called Sumak Kawsay promises to question the relationship of dependence on countries that the literature calls central. More than a paradigm or way of thought, efforts were made to translate this ideology into political and social guidelines by securing the rights of nature and declaring thisAndean country as plurinational in the Constitution of 2008.

On the part of the government, the strength of its vertex resided in the fact that several institutional mechanisms were actually produced which could provide its foundations. However, through the content analysis we found a disarticulation and a distance between the discourses developed in the documents. This fragmentation may have been responsible for the isolated results observed so far.

The change in the production framework as a development alternative could be possible in the encounter of the three vectors indicated by Sábato. However, it would also be necessary to invest in businesses' knowledge and in recognizing their strength, interests, resources and willingness to invest in innovation. In addition, fostering alliances with other higher education institutions could reduce resistance to that. The isolation of Yachay is also considered a weakness in the production framework change dynamics since there has been no evidence of a conscious and concerted selective strategy to integrate businesses and society into this project in practice.

The strategy of the country's Vice-President's office also shows some gaps and disarticulations between the three vertices, as we found in the documentary analysis. Likewise, the new industrial development policy, in effect until 2025, aims to reduce external vulnerability, increase productivity, createjobs, strengthen businesses, boost innovation and improve links with other sectors. However, this policydoes not articulatewith scientific development.

Our main findings were that the obstacles identified reside mainly in problems of management and disarticulation between vertices - whether concerning their functionality, their importance or the responsibility they should assume. Moreover, it is worth noting that, philosophically, the government's proposal based on the indigenous concept ofSumak Kawsayis essentially about strengthening a society that is constitutive of its territory, critical and participatory of its surroundings. However, with the fragmentation observed, this goal is far from being achieved. When time came to implement the production framework change strategy, the logic guiding governmental action was closer to Henry Etzkowitz' triple helix proposal.Nevertheless, its philosophical foundations are more akin to the discussion that founds Jorge Sábato's proposal. Amidst this disagreement, which still predominates, the actors should reconsider their roles. 


\title{
Desenvolvimento e território: potencialidades da cidade do conhecimento Yachay, Equador
}

\author{
RESUMO
}

O objetivo da pesquisa consistiu em evidenciar o conceito de desenvolvimento desde a perspectiva dos povos originários andinos de Sumak Kawsay, que se posicionou como um discurso contra-hegemônico e questionador da dicotomia de países periféricos-centrais. Na reconstrução de nosso argumento, a visão ideológica do Buen Vivir - Sumak Kawsay enlaçada com a proposta do triângulo de Jorge Sábato sustentam as propostas de um Estado Inovador na transposição da visão de dependência e de um país como Equador, considerado periférico no contexto atual. Para tanto, se propôs a analisar um caso de estudo, o da Cidade do Conhecimento Yachay, um complexo de inovação em que deveriam conviver sociedade, universidade e empresas, e que neste artigo será analisado pela potencialidade que teria pelo seu conceito originário. A pesquisa foi realizada a partir de informação bibliográfica e documental, cujos dados foram analisados por meio de análise de conteúdo. Como principais achados, se considera que os obstáculos encontrados residem principalmente em problemas de gestão e de desarticulação entre os vértices do Triângulo de Sábato (onde estão representados o Estado, a Infraestrutura de pesquisas e o Tecido Empresarial) - seja em sua funcionalidade, seja em sua importância ou na responsabilidade que deveria assumir.

PALAVRAS-CHAVE:Desenvolvimento; Sumak Kawsay; Cidade do Conhecimento Yachay; Equador 


\section{REFERENCES}

Arrighi, Giovani. A ilusão do desenvolvimento. Rio de Janeiro: Editora Vozes, 1997.

Bardin, Laurence. El análisis de contenido. Madrid: Akal, 2002.

Bianchi, M., Perini, A. \& León, C., Transformaciones de la participación política en América Latina. Asuntos del Sur. Buenos Aires. La versión original de este documento fue publicada en diciembre de 2016 por la Revista Eletrônica de Ciência Política (DOI: http://dx.doi.org/10.5380/recp.v7i2.48528) 2017.

Braña, Francisco Javier. Domínguez, Rafael. León, Maurício. Buen Vivir y cambio de la matriz productiva: reflexiones desde el Ecuador. Cantabria: editorial de la Universidad de Cantabria, ES. Impreso en Quito, Ecuador, 2016.

Brosius, J. Peter. Anna Lowenhaupt Tsing, Charles Zerner. Representing communities: Histories and politics of community-based natural resource management. Society and Natural Resources, Vol. 11, 1998, pp. 157-168.

Caravaca Barroso, Inmaculada, García García, Antonio. El debate sobre los territorios inteligentes: el caso del área metropolitana de Sevilla EURE, vol. XXXV, núm. 105, agosto, 2009, pp. 23-45 Pontifícia Universidad Católica de Chile Santiago, Chile.

Cobey, Ryan \& Bandeira, Mariana Lima. Public policy and the indigenous influence in Ecuador: Well being and pluri-nationality within a framework of 'Buen Vivir'. In: 8th Iberoamerican Academy Conference, 2013. São Paulo, Brasil, Diciembre 2013. Anais IAM, 2013

Cobey, Ryan \& Bandeira, Mariana. "Sumak Kawsay or Buen Vivir", an alternative development model in the Andean State? Farol Revista de Estudos Organizacionais e Sociedade: Farol - Revista de Estudos Organizacionais e Sociedade, v. 3, p. 481-537, 2016.

ECUADOR. Estrategia Nacional de Cambio de la Matriz Productiva. Quito, 
ECUADOR. Expediente de Creación de YACHAY. Tomos I, II y III. Quito, SENPLADES, 2013.

ECUADOR. Plan Nacional del Buen Vivir, PNBV. Quito, SENPLADES. Versión 1 (2007-2010), 2006.

ECUADOR. Plan Nacional del Buen Vivir, PNBV. Quito, SENPLADES. Versión 2 (2009-2013), 2008.

ECUADOR. Plan Nacional del Buen Vivir, PNBV. Quito, SENPLADES. Versión 3 (2013-2017), 2012.

ECUADOR. SENPLADES, Informe técnico: Identificación de la sede para la Ciudad del Conocimiento. República del Ecuador, SENPLADES, Noviembre, 2011.

ECUADOR. YACHAY, PLAN MAESTRO. Quito, SENPLADES, 2013. Disponible en: http://www.yachay.gob.ec/plan_maestro/

Eisenhardt, K. Building theories from Case Study Research. The Academy of Management Review, Vol. 14, No. 4, Oct. 1989, pp. 532-550.

Ergazakis, K., Metaxiotis, K., Psarras, J., Askounis, D. A unified methodological approach for the development of knowledge cities. Journal of Knowledge Management, Vol. 10, núm. 5, 2006, p. 65-78.

Etzkowitz, Henry \& Zhou, Chunyan. Hélice tríplice: inovação e empreendedorismo universidade-indústria-governo. Estudos Avançados, vol. 31, no. 90, 2017. Pp. 2348.

Etzkowitz, Henry and Leydesdorff, Loet. The endless transition: A "Triple Helix" of University-Industry-Government relations: Introduction. Minerva, Vol. 36, No. 3, Autumn, 1998, pp. 203-208.

Etzkowitz, Henry. Enterprises from Science: The Origins of Science-based Regional Economic Development. Minerva, Vol. 31, No. 3 (September 1993), pp. 326-360.

Etzkowitz, Henry. The norms of entrepreneurial science: cognitive effects of the new university-industry linkages. Research Policy, Vol. 27, 1998, pp. 823-833. 
Gudynas, E. "Buen Vivir: Germinando Alternativas al Desarollo" América Latina enMovimiento, 2011.

Herrera, Amílcar O. Introducción: notas sobre la ciencia y la tecnología en el desarrollo de la sociedad latinoamericana. En: Herrera, Amílcar O. (Organizador). América Latina: Ciencia y Tecnología en el desarrollo de la sociedad. Colección Tiempo Latino Americano. Santiago de Chile: Editorial Universitaria, 1970.

Hsieh, Hsiu-Fang and Shannon, Sarah E. Three Approaches to Qualitative Content Analysis. Qualitative Health Research, Vol. 15 No. 9, November 2005, pp. 12771288. DOI: $10.1177 / 1049732305276687$

Mazucatto, Mariana. O estado emprendedor. Sao Paulo, Cia das Letras, 2013.

Romeiro, Patrícia. Ricardo Méndez Gutiérrez del Valle. Las ciudades del conocimiento: revisión crítica y posibilidades de aplicación a las ciudades intermedias. X Coloquio Internacional de Geocrítica - DIEZ AÑOS DE CAMBIOS EN EL MUNDO, EN LA GEOGRAFÍA Y EN LAS CIENCIAS SOCIALES, 1999-2008. Barcelona, $26 \quad-\quad 30$ de mayo de 2008 Universidad de Barcelona. Disponible en: http://www.ub.edu/geocrit/xcol/407.htm\#_edn1

Sábato, Jorge. Botana, Natalio. La ciencia y la tecnología en el desarrollo futuro de América Latina. Primera Reunión del Comité de Patrocinio y Política del Estudio Prospectivo sobre América Latina y el Orden Mundial en la Década de 1990 que tuvo lugar en Santiago de Chile en Noviembre de 1967.

Sábato, Jorge. Botana, Natalio. La ciencia y la tecnología en el desarrollo futuro de América Latina. Revista de la Integración, No. 3, Buenos Aires, Noviembre, 1968. (recuperado en el libro organizado por Sábato, Jorge. El pensamiento latinoamericano en la problemática ciencia-tecnología-desarrollo-dependencia. Buenos Aires: Paidós, 1975.

Sábato, Jorge. Botana, Natalio. La ciência y la tecnología en el desarrollo de América Latina. En: Herrera, Amílcar O. (Organizador). América Latina: Ciencia y Tecnología en el desarrollo de la sociedad. Colección Tiempo Latino Americano. Santiago de Chile: Editorial Universitaria, 1970.

Sábato, Jorge. Ensayos en Campera. Quilmes, Argentina: Universidad Nacional de Quilmes Editorial, 2004. 
Santiago, Ana Lúcia Frezzatti. Jacques Demajorovic. Licença social para operar: um estudo de caso a partir de uma indústria brasileira de mineração social. ENGEMA, 2016.

Santos Milton. A Natureza do Espaço- técnica e Tempo, Razão e Emoção. São Paulo: Universidade de São Paulo, 2002.

Santos Milton. Por uma outra globalização, do pensamento único à consciência universal. Rio de Janeiro: Editora Record, 2000.

Santos, Elinaldo L.; Braga, Victor; Santos, Reginaldo S., Braga, Alexandra M. da S. Desenvolvimento: um conceito multidimensional. DRd - Desenvolvimento Regional em debate, Ano 2, n. 1, jul. 2012.

Santos, Theotonio. Desarrollo, crisis y dependência. En: Del Valle Rivera, Maria del Carmen \& Jasso Villazul, Sergio Javier (compiladores). Tomo III. México: UNAM, 2015.

Silva, Klaus Pereira de. \& Guedes, Ana Lúcia. Buen Vivir Andino: Resistência e/ou alternativa ao modelo hegemónico de desenvolvimento. Cad. EBAPE.BR, v. 14, no 3, Artigo 8, Rio de Janeiro, Jul./Set. 2017.

Sunkel, Osvaldo. El marco histórico del proceso de desarrollo y subdesarrollo. Cuadernos ILPES, Serie II, No. 1, Santiago de Chile, 1967.

Villavicencio, Arturo. Innovación, matriz productiva y universidad: Por qué Yachay es una estrategia equivocada. Quito: Fundación Hernán Malo González, Corporación Editora Nacional, 2014.

Villavicencio, Arturo. La universidad virtuosa. Quito, UASB, 2015. Disponible en: http://portal.uasb.edu.ec/UserFiles/383/File/Ponencias\%20completas\%20Ecuad or\%202014/La\%20unviersidad\%20virtuosa\%20Arturo\%20Villavicencio.pdf

Villavicencio. Arturo. ¿Hacia dónde va el proyecto universitario de la revolución ciudadana? Quito, UASB, 2013 (mimeo). Disponible en: http://repositorio.uasb.edu.ec/bitstream/10644/3235/1/Villavicencio,\%20ACON-001-Hacia\%20donde.pdf

Walsh, C. "Development as Buen Vivir: Institutional arrangements and (de)colonial entanglements" Development, Vol. 53, No. 1, 2010, pp. 15-21. 
Recebido: 17 jun. 2018.

Aprovado: 19 ago. 2018

DOI: $10.3895 /$ rbpd.v7n4.8516

Como citar: BANDEIRA, M. L.; GUEDES, C. A. M.; LÓPEZ-PARRA, M. F. Development and territory: potentialities of the Yachay city of knowledge in Ecuador. R. bras. Planej. Desenv.,Curitiba, v. 7, n. 4, p.495515, set./dez. 2018.Disponível em: <https://periodicos.utfpr.edu.br/rbpd>. Acesso em: XXX.

Correspondência:

Mariana Lima Bandeira

Toledo, Quito 170109, Equador

Direito autoral: Este artigo está licenciado sob os termos da Licença CreativeCommons-Atribuição 4.0 Internacional.

\section{(c) (1)}

